УДК 621.762:621.315.5

๑ В. О. Кохановський, к.т.н., доцент, НТУУ «КПІ», Київ, Україна

\title{
ВИЗНАЧАЛЬНІ ФАКТОРИ ЗНОСОСТІЙКОСТІ КОНТАКТІВ ЕЛЕКТРОМЕХАНІЧНИХ КОМУТАЦІЙНИХ АПАРАТІВ
}

У статті узагальнено та систематизовано фактори, які впливають на зносостійкість і функціональність контактів комутаційних апаратів. Для цього було проаналізовано види зносу, яким піддається електричний апарат під час експлуатації та визначено властивості контактного матеріалу - механічні, фізичні, хімічні, структурні, які зменшують переважаючий вид зносу залежно від режимів роботи і умов експлуатації апарату. Також наведено перелік параметрів комутуючого кола і пристроїв електричних апаратів, які впливають на процеси зношення матеріалу контактів та загальні положення щодо вибору типу матеріалу, якими необхідно керуватися при розробці контактної системи для електромеханічних комутаційних апаратів.

Ключові слова: електричні контакти, комутаційні апарати, зносостійкість, контактні матеріали, експлуатаційні характеристики, властивості матеріалів.

\section{Постановка проблеми}

Надійна робота електромеханічного комутаційного апарату залежить перш за все від безвідмовної роботи його контактної системи. Контакти в процесі експлуатації піддаються впливу численних факторів, внаслідок чого можуть відбуватися неналежне функціонування апарату, передчасне зношення контактів, порушення електропровідності та інші негативні явища. Тому, визначення шляхів, які залежно від умов та режимів роботи, можуть забезпечити стабільність функціонування та необхідний ресурс служби є важливою задачею при розробці контактних систем комутаційних апаратів.

\section{Мета роботи}

Одним із напрямків удосконалення конструкції електричного апарату $€$ розробка контактного матеріалу з тими властивостями, які необхідні для належного функціонування при визначених умовах експлуатації. Визначення переліку таких властивостей, які зменшують негативний вплив експлуатаційних факторів і $€$ метою даної роботи.

Основні вимоги до контактів електромеханічних комутаційних апаратів

Комутуючі пристрої електричних апаратів під час експлуатації зазнають впливу наступних факторів, які призводять до таких руйнувань [1]: 


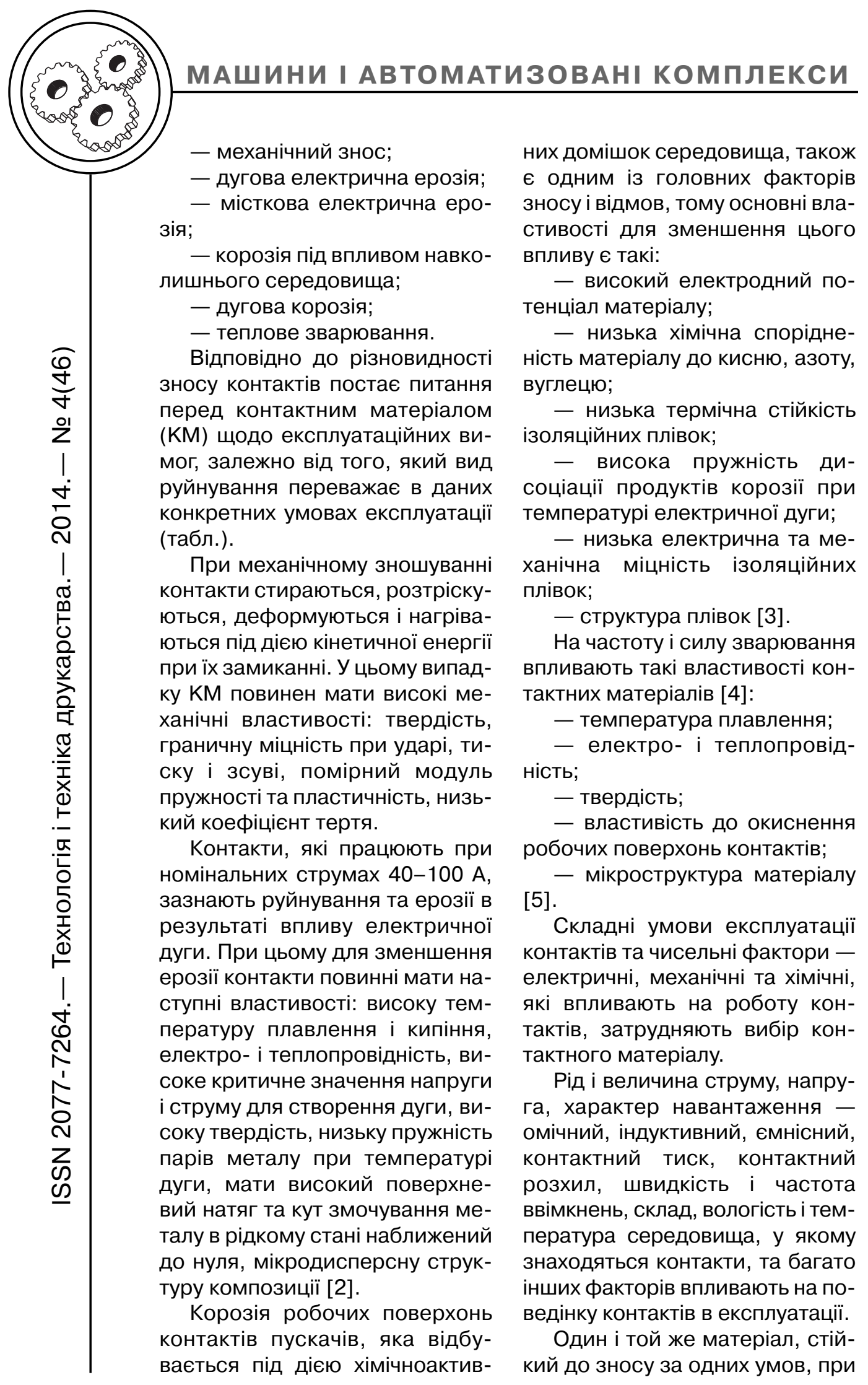




\section{МАШИНИ І АВТОМАТИЗОВАНІ КОМПЛЕКСИ}

Властивості контактного матеріалу, які зменшують переважаючий вид зносу

\begin{tabular}{|c|c|c|c|}
\hline Вид зносу & $\begin{array}{l}\text { Зовнішні факто- } \\
\text { ри, які виклика- } \\
\text { ють знос }\end{array}$ & $\begin{array}{c}\text { У чому виража- } \\
\text { ється знос }\end{array}$ & $\begin{array}{c}\text { Властивості матеріалу } \\
\text { контактів, які впливають } \\
\text { на знос }\end{array}$ \\
\hline Механічний & $\begin{array}{l}\text { Контактний на- } \\
\text { тиск. Кінетична } \\
\text { енергія удару } \\
\text { контактів при } \\
\text { замиканні. Про- } \\
\text { ковзування при } \\
\text { замиканні }\end{array}$ & $\begin{array}{l}\text { Розплющування, } \\
\text { розтріскування, } \\
\text { стирання кон- } \\
\text { тактів }\end{array}$ & $\begin{array}{l}\text { Високі механічні властивості: } \\
\text { твердість, гранична міцність } \\
\text { при ударі, тиску і зсуві, помі- } \\
\text { рний модуль пружності, гус- } \\
\text { тини та пластичності, низь- } \\
\text { кий коефіцієнт тертя. Постій- } \\
\text { ність властивостей до } 300^{\circ} \mathrm{C} . \\
\text { Мікроструктура матеріалу. }\end{array}$ \\
\hline $\begin{array}{l}\text { Ерозія: } \\
\text { а) місткова }\end{array}$ & $\begin{array}{l}\text { Плавлення кон- } \\
\text { тактних точок } \\
\text { струмом. Щіль- } \\
\text { ність струму } \\
\text { Енергія ду- } \\
\text { ги(іскри). Вид } \\
\text { струму. Індукти- } \\
\text { вність та ємність } \\
\text { кола }\end{array}$ & $\begin{array}{l}\text { Голкоутворення } \\
\text { на аноді. } \\
\text { Зчеплення } \\
\text { контактів. } \\
\text { Плавлення, ви- } \\
\text { паровування, } \\
\text { розбризкування } \\
\text { металу. Перенос } \\
\text { металу. Кратер } \\
\text { та нарости на } \\
\text { контактах. Знос } \\
\text { та деформація } \\
\text { контактів }\end{array}$ & $\begin{array}{l}\text { Високі електрофізичні власт- } \\
\text { вості: } \\
\text { Напруга і струм дугоутво- } \\
\text { рення. Температура кипіння, } \\
\text { плавлення та сублімації. } \\
\text { Скрита теплота плавлення та } \\
\text { випаровування. Електро- та } \\
\text { теплопровідність. Робота ви- } \\
\text { ходу електрона з кристаліч- } \\
\text { ної гратки. Потенціал іонізації } \\
\text { атому металу при випарову- } \\
\text { ванні. } \\
\text { Низькі електрофізичні влас- } \\
\text { тивості: величина коефіцієн- } \\
\text { та Томсона, кут змочування } \\
\text { металу в рідкому стані, пове- } \\
\text { рхневий натяг, пружність па- } \\
\text { рів металу при температурі } \\
\text { дуги, термоелектрорушійна } \\
\text { сила. }\end{array}$ \\
\hline $\begin{array}{l}\text { Корозія: } \\
\text { а) атмос- } \\
\text { ферна }\end{array}$ & $\begin{array}{l}\text { Температура та } \\
\text { вологість сере- } \\
\text { довища. Наяв- } \\
\text { ність хімічно ак- } \\
\text { тивних домішок. } \\
\text { Наявність мікро- } \\
\text { і макрогальва- } \\
\text { нічних пар. На- } \\
\text { явність пилу та } \\
\text { органічних ви- } \\
\text { паровувань. } \\
\text { Температура та } \\
\text { енергія дуги. } \\
\text { Рухливість дуги }\end{array}$ & $\begin{array}{l}\text { Створення } \\
\text { «непровідних» } \\
\text { плівок, обгорян- } \\
\text { ня контактів }\end{array}$ & $\begin{array}{l}\text { Високі електрохімічні влас- } \\
\text { тивості: } \\
\text { Електрохімічний потенціал. } \\
\text { Пружність дисоціації продук- } \\
\text { тів корозії } \\
\\
\text { Низькі електрохімічні власти- } \\
\text { вості: Спорідненість до кис- } \\
\text { ню, сірки та азоту. Термічна } \\
\text { стійкість плівок. Електрична } \\
\text { та механічна міцність плівок. } \\
\text { Товщина та структура плівок. }\end{array}$ \\
\hline
\end{tabular}




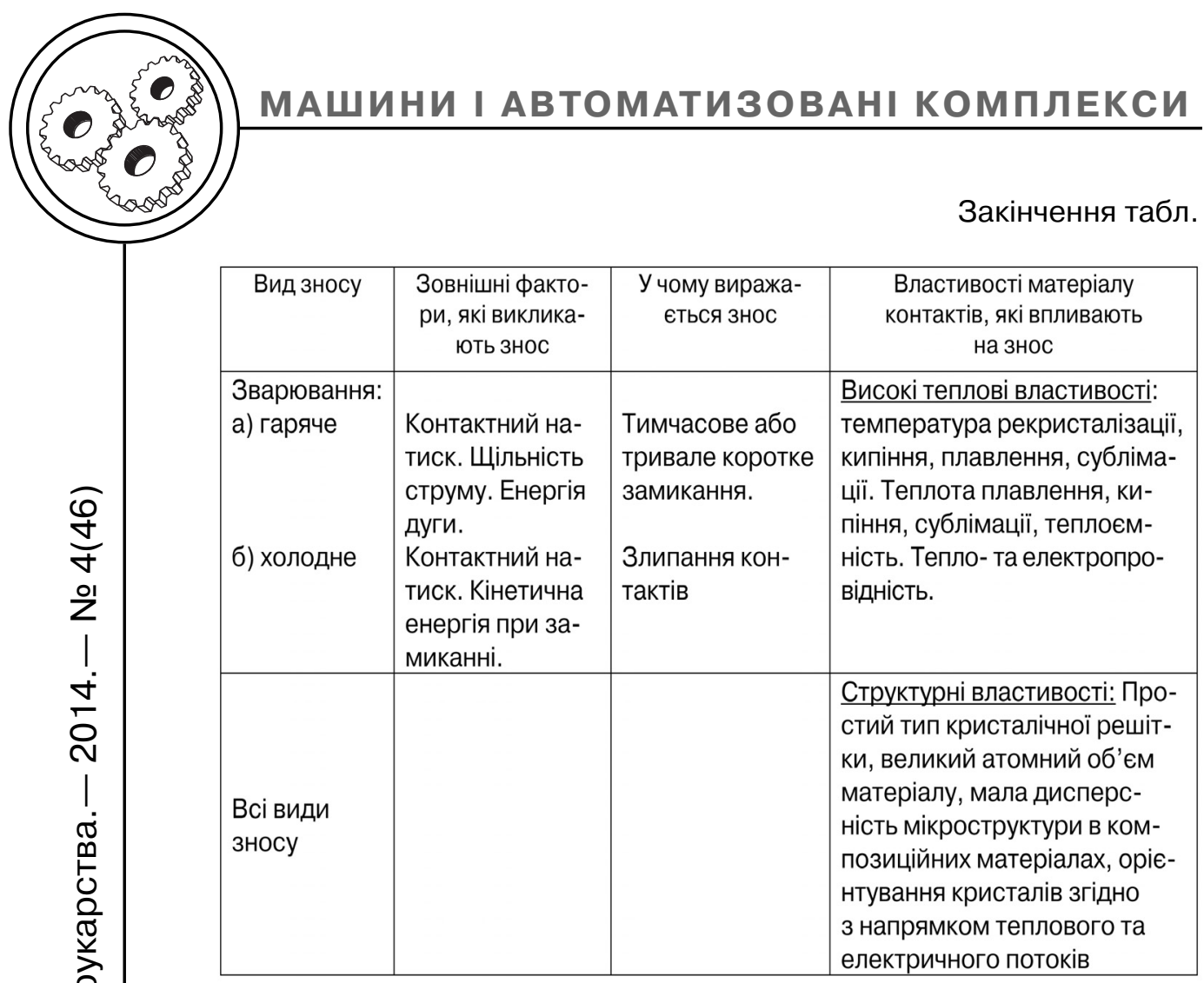

зміні одного із факторів може виявитися зовсім непридатним для роботи.

У загальному вигляді контакти повинні характеризуватися наступними фізичними параметрами:

- стабільністю контактного перехідного опору;

- високою питомою електропровідністю;

- високою ерозійною стійкістю та корозійною тривкістю;

- високою дугостійкістю і стійкістю до зварювання;

- поєднанням механічної міцності та високої пластичності [6].

Практично неможливо підібрати універсальний матеріал, який би відповідав усім названим вимогам, тому залежно від функціонального призначення контактного вузла доводиться приймати компромісне рішення.
Контакти електричних апаратів, які працюють в області малих та середніх струмів, повинні, перш за все, забезпечувати стабільність перехідного опору в поєднанні з високими дугостійкістю та стійкістю до зварювання [7].

Перехідний опір залежить від фактичної площі дотику контактів і від питомого опору контактного матеріалу. Ефективна площа контактування залежить від величини контактного натиску і з його ростом збільшується за експоненціальною залежністю до того часу, поки напруга стискання не буде вищою за межу текучості матеріалу. 3 іншого боку, перехідний опір залежить від опору граничного шару, який визначається його складом (наявність оксидних, сульфідних та інших плівок, пилу тощо) і питомим електричним опором [8]. 
У кожному окремому випадку при розробці контактної системи для електромеханічних комутаційних апаратів необхідно керуватися деякими загальними положеннями, головні з них наведено нижче.

Фактори, що впливають на експлуатаційні характеристики контактів електричних апаратів

До головних факторів, які обумовлюють роботу контактів електричних апаратів, на думку автора, відносяться наведені нижче:

1. Параметри комутуючого кола:

- величина номінального струму. Чим більша величина номінального струму, тим сильніше нагрівання контактів. Перевагу мають метали з високою тепло- і електропровідністю, які не окислюються при малому контактному натиску;

- рід струму. Електрична ерозія контактів більш виражена при постійному струмі. При змінному струмі перенос матеріалу зменшується, але більше піддається ерозії контакт, температура якого вища. Збільшується оплавлення та обгоряння $\mathrm{KM}$;

- комутуючий струм. При струмі нижче за граничний, електрична дуга не виникає. При збільшенні струму вище за граничний (коли з'являється дуга), явища ерозії, зварювання, окиснення та обгоряння зростають разом 3 енергією дуги і струмом;

- напруга між контактами. Вона визначає виникнення контактної дуги. Нижче граничного значення (для кожного КМ своє значення) - дуга не вини- кає, вище - з'являється контактна дуга;

- характер навантаження. Залежно від характеру навантаження змінюються пускові струми, які комутують пускачі, а також від значення cos змінюється індуктивність кола. Це призводить до виникнення перенапруг і до збільшення часу горіння дуги та ерозії при комутації, а також сприяе зварюванню контактів;

- наявність чи відсутність дугогасильних пристроїв;

- частота і загальна кількість комутаційних циклів прямо пропорційно впливають на інтенсивність і величину ерозії контактів. Завищена частота спричиняє перегрівання контактів вище за допустиму температуру.

2. Параметри комутуючих пристроїв електричних апаратів:

- номінальний контактний натиск. Незначний натиск зменшує ерозію матеріалу, але спричиняє підвищення перехідного контактного опору. При достатньо великих зусиллях можна застосовувати матеріали, які окислюються, зважаючи при цьому на характеристики механічної міцності;

- конструктивні фактори. Деренчання контактів при замиканні значно збільшує ерозію і зварювання внаслідок послідовних комутаційних операцій пускового струму;

- швидкість контактів при комутації. Збільшення швидкості при розмиканні скорочує час горіння дуги при постійному струмі, зменшуючи ерозію. Велика швидкість при змінному 


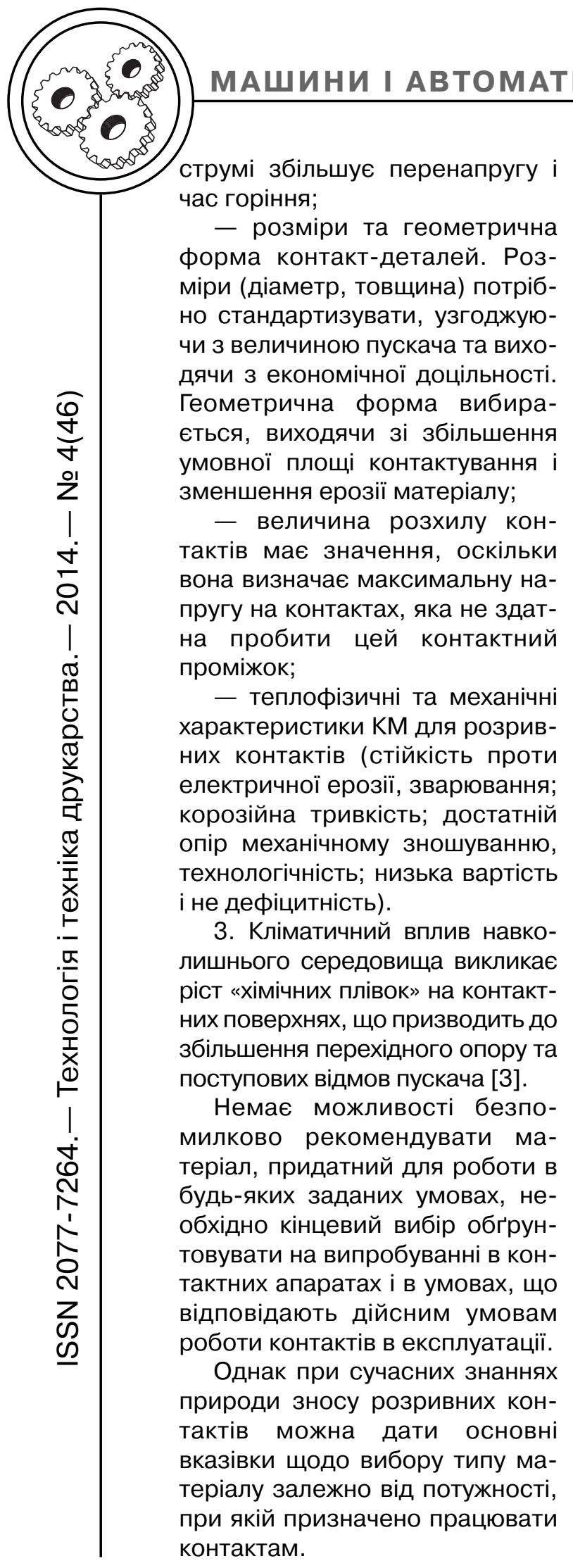

Для малонавантажених контактів, що працюють нижче межі дугоутворення і піддаються містковій ерозії, найбільш придатні метали з високою тепло- і електропровідністю. Допустиме слабке легування іншими металами, в тому числі і неблагородними, 3 метою підвищення твердості і зменшення голкоутворення [9].

Для середньонавантажених контактів, які працюють з утворенням контактної дуги, придатні туготопкі метали, а також сплави типу твердих розчинів. Для зменшення зварювання доцільно вводити в сплав або композицію оксиди металів, які при певних умовах дисоціюють, не порушуючи контактної провідності [10].

Для високонавантажених контактів найбільш придатні композиції, які поєднують високу зносостійкість тугоплавких металів та електро- і теплопровідність, наприклад, $\mathrm{Cu}$ чи $\mathrm{Ag}$.

\section{Висновки}

У статті узагальнено та систематизовано фактори, які впливають на зносостійкість і функціональність контактів комутаційних апаратів. Для цього було проаналізовано види зносу, яким піддається електричний апарат під час експлуатації та визначено властивості контактного матеріалу - механічні, фізичні, хімічні, структурні, які зменшують переважаючий вид зносу залежно від режимів роботи і умов експлуатації апарату. Також наведено перелік параметрів комутуючого кола i пристроїв електричних апаратів, які впливають на процеси зношення матеріалу контактів та загальні положення щодо 
вибору типу матеріалу, якими необхідно керуватися при розробці контактної системи для електромеханічних комутаційних апаратів.

Результати дослідження можуть використовуватися при вирішенні задач підвищення експлуатаційних характеристик електричних апаратів шляхом розробки і застосування нових контактних матеріалів, удосконалення конструкції контактних та дугогасних систем та ін.

\section{Список використаної літератури}

1. Пархоменко И. В. Анализ эрозионных процессов на контактах при коммутации тока в различных средах / И. В. Пархоменко // Электрические низковольтные аппараты. - К. : Техніка, 1975. - 305 с.

2. Минакова Р. В. Композиционные материалы для контактов и электродов (Обзор) / Р. В. Минакова, М. Л. Грекова, А. П. Кресанова, Л. А. Крячко // Порошковая металлургия. - 1995. - № 7/8. - С. 32-53.

3. Кальман И. Г. Воздействие факторов внешней среды на аппаратуру и элементы / И. Г. Кальман. - М. : Знание, 1971.

4. Берберов А. Э. Свариваемость контактов под действием импульсных токов / А. Э. Берберов, Е. В. Володина, В. Г. Дегтярь, В. А. Моргунов // Пути повышения ресурса и надежности электрических аппаратов. - Сб. научн. тр. МЭИ. - 1988. - № 167. - С. 39-43.

5. Афонин М. П. Класификация материалов для электрических контактов низковольтной коммутационной аппаратуры и области их применения в элекротехнике. - Электрические контакты и электроды / М. П. Афонин, М. Н. Овчинникова // Труды Института материаловедения им. И. Н. Францевича НАН Украины. - Киев, 2006. - С. 153-160.

6. Справочник по расчету и конструированию контактных частей сильноточных электрических аппаратов / [Под ред. В. В. Афанасьева.] Л. : Энергоатомиздат, 1988. - 381 с.

7. Контактори електромагнітні низьковольтні. Загальні технічні умови : ДСту 2846-94. - [чинний від 01.01.1996]. - К. : Держспоживстандарт України, 2006. - 18 с. - (Національні стандарти України).

8. Копытин Ф. А. Сравнительные соотношения расчетных и экспериментальных данных сопротивления электрических контактов / Ф. А. Копытин // Электротехническая промышленность. Серия «Аппараты низкого напряжения». - 1971. - № 7. - С. 12-15.

9. Разумихин М. А. Эрозионная устойчивость маломощных контактов / М. А. Разумихин. - Л. : Энергия, 1964. - 83 с.

10. Клименко Б. В. Огляд та перспективи розвитку матеріалів для контактів електромеханічних апаратів низької напруги / Б. В. Клименко, В. О. Кохановський // Електротехніка і електромеханіка. - Харків : НТУ «ХП|». - 2011. - № 4. - C. 34-40.

\section{References}

1. Parhomenko I. V. Analiz jerozionnyh processov na kontaktah pri kommutacii toka v razlichnyh sredah / I. V. Parhomenko // Jelektricheskie nizkovol'tnye apparaty. - K. : Tehnika, 1975. - 305 c.

2. Minakova R. V. Kompozicionnye materialy dlja kontaktov i jelektrodov (Obzor) / R. V. Minakova, M. L. Grekova, A. P. Kresanova, L. A. Krjachko // Poroshkovaja metallurgija. - 1995. - № 7/8. - S. 32-53.

3. Kal'man I. G. Vozdejstvie faktorov vneshnej sredy na apparaturu i jelementy / I. G. Kal'man. - M. : Znanie, 1971. 
4. Berberov A. Je. Svarivaemost' kontaktov pod dejstviem impul'snyh tokov / A. Je. Berberov, E. V. Volodina, V. G. Degtjar', V. A. Morgunov // Puti povyshenija resursa i nadezhnosti jelektricheskih apparatov. - Sb. nauchn. tr. MJel. 1988. - № 167. - S. 39-43.

5. Afonin M. P. Klasifikacija materialov dlja jelektricheskih kontaktov nizkovol'tnoj kommutacionnoj apparatury i oblasti ih primenenija v jelekrotehnike. Jelektricheskie kontakty i jelektrody / M. P. Afonin, M. N. Ovchinnikova // Trudy Instituta materialovedenija im. I. N. Francevicha NAN Ukrainy. - Kiev, 2006. S. $153-160$.

6. Spravochnik po raschetu i konstruirovaniju kontaktnyh chastej sil'notochnyh jelektricheskih apparatov / [Pod red. V. V. Afanas'eva.] - L. : Jenergoatomizdat, 1988. - $381 \mathrm{~s}$.

7. Kontaktory elektromahnitni nyzkovoltni. Zahalni tekhnichni umovy : DSTU 2846-94. - [chynnyi vid 01.01.1996]. - K. : Derzhspozhyvstandart Ukrainy, 2006. - 18 s. - (Natsionalni standarty Ukrainy).

8. Kopytin F. A. Sravnitel'nye sootnoshenija raschetnyh i jeksperimental'nyh dannyh soprotivlenija jelektricheskih kontaktov / F. A. Kopytin // Jelektrotehnicheskaja promyshlennost'. Serija «Apparaty nizkogo naprjazhenija». - 1971. - № 7. - S. 12-15.

9. Razumihin M. A. Jerozionnaja ustojchivost' malomoshhnyh kontaktov / M. A. Razumihin. - L. : Jenergija, 1964. - $83 \mathrm{~s}$

10. Klymenko B. V. Ohliad ta perspektyvy rozvytku materialiv dlia kontaktiv elektromekhanichnykh aparativ nyzkoi napruhy / B. V. Klymenko, V. O. Kokhanovskyi // Elektrotekhnika i elektromekhanika. - Kharkiv : NTU «KhPI». - 2011. - № 4. - S. 34-40.

В статье приведен обзор факторов влияния на эксплуатационные характеристики контактов электромеханических коммутационных аппаратов и пути повышения их износостойкости.

Ключевые слова: электрические контакты, коммутационные аппараты, износостойкость, контактные материалы, эксплуатационные характеристики, свойства материалов.

This article provides an overview of factors influence to the operating characteristics of contacts of electromechanical switching devices and ways to improve their durability.

Keywords: electrical contacts, switching devices, durability, contact's materials, operating characteristics, material properties.

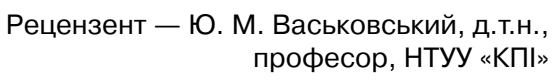
професор, НТУУ «КП।»

Надійшла до редакції 16.12.14 